\title{
Cruise tourism in the Red Sea
}

\author{
Olena Budz ${ }^{1}$, Oksana Romaniv ${ }^{1}$, Olga Milinchuk ${ }^{2}$, and Dina Yarmolyk ${ }^{2 *}$ \\ ${ }^{1}$ National University of Water and Environmental Engineering, 11 Soborna St., 33028, Rivne, \\ Ukraine \\ ${ }^{2}$ Zhytomyr Polytechnic State University, 103 Chudnivska St., 10005, Zhytomyr, Ukraine
}

\begin{abstract}
Cruising is a lifestyle that involves living for extended time on a boat while traveling from place to place for pleasure. Cruise lines have a dual character; they are partly in the transportation business, and partly in the leisure entertainment business, a duality that carries down into the ships themselves, which have both a crew headed by the ship's captain, and a hospitality staff headed by the equivalent of a hotel manager. The business is extremely volatile. Cruise lines frequently sell, renovate, rename their ships just to keep up with travel trends. That is why the aims of the study were to focus on the development of cruise tourism in the Red Sea, to characterize the major cruise lines in the Red Sea. There are 11 cruise lines that operate in the Red Sea. Cruise line rating scores were developed in this study. The Royal Caribbean International is a leader. The Oceania Cruises is an outsider. The primary reasons that consumers will be motivated to book a cruise: good value offered by the cruise lines; love of cruising; get away with friends or alone; family reunions, honeymoons/weddings/anniversaries; try out new sustainable ships; shorter cruises; and «work and play» opportunity.
\end{abstract}

\section{Introduction}

Travel on cruise ships may be referred to as cruising. Cruising generally refers to trips of a few days or more, and can extend to round-the-world voyages.

A cruise line is a company that operates cruise ships. Among cruise lines, some are direct descendants of the traditional passenger shipping lines, while others were founded from the 1960s on specifically for cruising. The business is extremely volatile; the ships are massive capital expenditures with very high operating costs, and a slight dip in bookings can easily put a company out of business. Cruise lines frequently sell, renovate, or simply rename their ships just to keep up with travel trends. A wave of failures and consolidation in the 1990s has led to many lines existing only as "brands" within larger corporations, much as a single automobile company produces several makes of cars. Brands exist partly because of repeat customer loyalty, and also to offer different levels of quality and service. For instance, Carnival Corporation owns both Carnival Cruise Lines, whose former image were vessels that had a reputation as "party ships" for younger travellers, but have become large, modern, and extremely elegant, yet still profitable, and Holland America Line, whose ships cultivate an image of classic elegance.

\footnotetext{
* Corresponding author: dina.yarmolyk@gmail.com
} 
Currently the five largest cruise line operators in the world are Carnival Corporation \& plc, Royal Caribbean Cruises Ltd., Star Cruises, Mediterranean Shipping Company (MSC) Cruises and Louis Cruises Lines [1].

Most cruise ships are centered around the Caribbean and Mediterranean.

The Red Sea is one of the world's top mass tourism destinations and tourist flows to this region are constantly increasing. However, the development of cruising in this region not described in scientific publications enough. It is therefore very important to explore the cruising in the Red Sea.

\section{Characteristics of the major cruise lines in the Red Sea}

There are 11 cruise lines operate in the Red Sea: Azamara Club Cruises, Costa Cruises, Cunard Line, Holland America Line, MSC Cruises, Oceania Cruises, Princess Cruises, Regent Seven Seas Cruises, Royal Caribbean International, Seabourn Cruise Line, Silversea Cruises.

Cruise line rating scores were developed for specific characteristics in this study: 0 point - no response; 1 point - is not on all ships; 2 points - is available on all ships.

It is best to focus on the services, programs when making evaluation rather than using the price, client's lifestyle or client's age as deciding factors. The following characteristics have been included for compiling the rating (table 1).

The Royal Caribbean International is a leader (144 points). The Oceania Cruises is an outsider (95 points) (Fig. 1).

Let's describe the key characteristics of the leader and outsider of our rating now.

Royal Caribbean International is a leading, innovative cruise vacation company. Guests are active travelers who are looking for new experiences, a wide array of choices for the whole family (from activities onboard all ships like rock climbing, surfing and ice skating to shoreside adventures like glacier trekking and exploring Mayan ruins). The brand is distinguished by interesting Gold Anchor Service, shoreside adventures, innovative ships.

Oceania Cruises is the world's upper-premium cruise line. This includes the finest cuisine at sea, carefully crafted by world-renowned Master Chef Jacques Pepin. Each ship offers the flexibility of open-seating dining in four unique restaurants and all specialty restaurants are complimentary. The warm and welcoming country club atmosphere encourages guests to dress comfortably, suits, tuxedos and gowns are never required. Oceania Cruises sails to more than 350 ports around the globe. Featuring a fleet of intimate and elegant mid-sized ships, Oceania Cruises is focused cruising overnight and multi-day stays in the world's most alluring ports. Therefore, the last described cruise line was lower in the rating due to fewer services. But it is also a prestigious cruise line.

Now thoroughly characterize the tourism product of one of the cruise lines.

For a cruise holiday of truly biblical proportions, there can be no better destination than the Red Sea - on board one of Mediterranean Shipping Company (MSC) Cruises' luxury liners.

Best of all, tourists can enjoy their Southern Sea experience from the first-class comfort of one of MSC Cruises' stylish cruise liners [2-3].

MSC Cruises has introduced what it calls the "perfect comprehensive itinerary" combining the cultures and nature experiences offered by Red Sea destinations. In addition to a full range of shore excursions, including historical tours in Egypt, Jordan and Israel, the cruises feature relaxation and snorkelling opportunities, and a variety of desert tours.

Themed menus and entertainment onboard are also designed to bring the region to life. According to MSC Cruises, menu items range from Mediterranean dishes to Arabian appetizers and traditional main courses, including marinated meats and fish dishes, tagines and couscous. 
Table 1. Characteristics for making evaluation of cruise line.

\begin{tabular}{|c|c|c|c|}
\hline Factors & Characteristics & Factors & Characteristics \\
\hline $\begin{array}{l}\text { 1. Stateroom } \\
\text { Amenities }\end{array}$ & $\begin{array}{c}\text { - TV/Radio } \\
\text { - CD Player } \\
\text { - In-Stateroom Movies } \\
\text { - iPod Docks/Stereos } \\
\text { - In-Stateroom Internet Access } \\
\text { - Direct Dial Telephone } \\
\text { - Private Safe } \\
\text { - Minibar/Refrigerator } \\
\text { - Hair Dryer }\end{array}$ & $\begin{array}{c}5 . \\
\text { Special } \\
\text { Programs/ } \\
\text { Services }\end{array}$ & $\begin{array}{c}\text { - Weddings/Honeymoon Packages } \\
\text { - Guest Lecturers/Educational } \\
\text { Programs } \\
\text { - Cell Phone Service } \\
\text { - iPod and/or iPhone Rental } \\
\text { - Special Dietary Needs (Advance } \\
\text { Notification Required) } \\
\text { - Wheelchair Accessibility }\end{array}$ \\
\hline $\begin{array}{c}2 . \\
\text { Dining }\end{array}$ & $\begin{array}{cc}\text { - } & \text { Traditional Assigned Seating } \\
-\quad \text { Open Seating } \\
\text { - Formal Nights } \\
\text { - } \quad \text { Specialty/a la carte Venues } \\
\text { - Coffeehouse/Patisserie } \\
\text { - } 24 \text { Hour Food Service Available }\end{array}$ & $\begin{array}{c}6 . \\
\text { Sports and } \\
\text { Fitness }\end{array}$ & 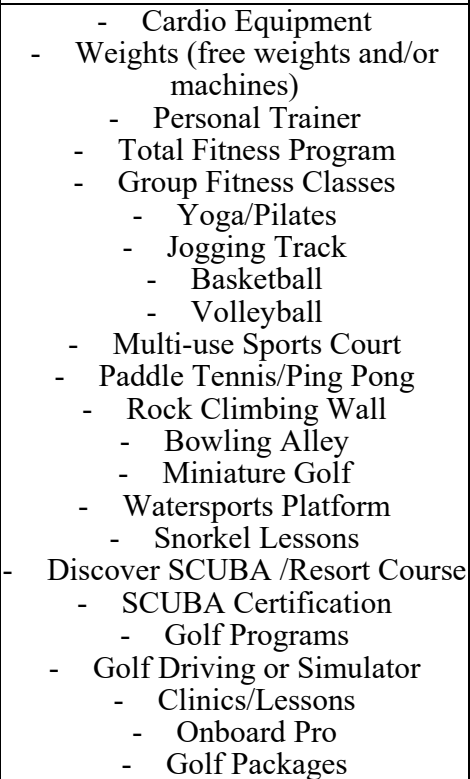 \\
\hline $\begin{array}{c}3 . \\
\text { Children and } \\
\text { Families }\end{array}$ & $\begin{array}{cc}\text { - } & \text { Family Staterooms } \\
\text { - } & \text { Reduced Cruise Rates } \\
- & \text { Babysitting Available } \\
\text { - Cribs Available } \\
\text { - Organized Age-Specific } \\
\text { Programs } \\
\text { - Games/Contests } \\
\text { - Organized Parties and Events } \\
-\quad \text { Organized Sporting Activities } \\
\text { - Cartoons } \\
\text { - Movies } \\
\text { - Educational Programs } \\
\text { - Environmental Awareness } \\
\text { - Programs } \\
\text { - Children-Only Pool } \\
\text { - Children's Playroom } \\
\text { - Teen Center or Disco } \\
\text { - Teen Counselors } \\
\text { - Youth Counselors }\end{array}$ & $\begin{array}{l}\text { 7. Spa/ } \\
\text { Wellness }\end{array}$ & $\begin{array}{c}\text { - } \text { Aromatherapy } \\
\text { - Body Wraps } \\
\text { - Mud Therapy } \\
\text { - Ionithermie Treatments } \\
\text { - Reflexology } \\
\text { - Thalassotherapy } \\
\text { - Massage } \\
\text { - Facials } \\
\text { - Manicure/Pedicure } \\
\text { - Full Service Beauty Salon } \\
\text { - Teeth Whitening } \\
\text { - Nutritionist } \\
\text { - Fitness Evaluations } \\
\text { - Steam Room or Sauna } \\
\text { - Jacuzzi or Whirlpool }\end{array}$ \\
\hline $\begin{array}{c}4 . \\
\text { Meetings } \\
\text { and } \\
\text { Conferences }\end{array}$ & $\begin{array}{cc}\text { - } & \text { Meeting Coordinator } \\
-\quad \text { Meeting Space } \\
-\quad \text { Conference Dining } \\
-\quad \text { Private Party/Events } \\
-\quad \text { Business Center Services } \\
-\quad \text { Audio Visual Equipment } \\
\text { - Computer Equipment } \\
\quad \text { - Email Access }\end{array}$ & & \\
\hline
\end{tabular}




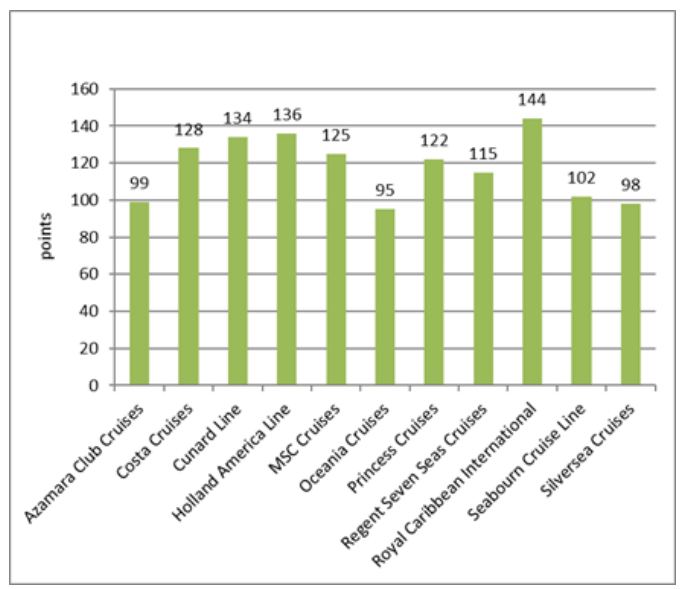

Fig. 1. Rating score of cruise lines (evaluated in points).

The ship's theatre will show the movies Cleopatra and A Queen's Life, "taking guests back to ancient Egypt". And for relaxation are sandy beaches and crystal clear water - "a haven for sunbathing or setting off on a discovery of the Red Sea's underwater world," according to MSC Cruises. Related tours are snorkeling excursions, trips in glass-bottomed boats, camel rides or jeep drives in the desert, or just floating in the saline waters of the Dead Sea for its alleged therapeutic effect [3].

Consider one typical cruise. [4] Parameters of studied route:

- Departing from: Sharm Ash Sheikh.

- Ports of call: Sharm Ash Sheikh, Safaga, Elat (Eilath), Aqaba, Sokhna Port.

- Duration: 7 nights.

Prices cruises in the Red Sea are lower than in other destinations [5].

\section{Market segmentation}

The cruise industry is segmented into types of cruises based on certain characteristics that define the on-board lifestyle and overall vacation experience.

Cruise lines fall also into loose categories that are generally termed Mainstream, Premium, and Luxury [6]. The First-Class cruise lines, (also known as the mass market lines), and the Premium cruise lines are resort-style vacations offering a broad base of services, destinations and amenities that are affordable to most travelers.

Over the past few years these lines have mimicked one another's successes so much that the two segments have merged in their "mass-clusivity" to create a large contemporary segment of the cruise market. Such cruise lines predominate in the Red Sea.

First Class Cruise Lines: Costa Cruises, Mediterranean Shipping Company (MSC) Cruises, Royal Caribbean International. Key Word: Quantity

Premium Cruise Lines: Azamara Club Cruises, Holland America Line, Oceania Cruises, Princess Cruises. Key Word: Quality.

The Figure 2 below illustrates a number of variables that predict cruise behaviour, and how they might aggregate to form market segments.

Consumer marketing segmentation was carried out in \%, using the methodology of scientific works [7-12] (table 2). «Explorers» are the largest segment among cruising consumers in the Red Sea. 


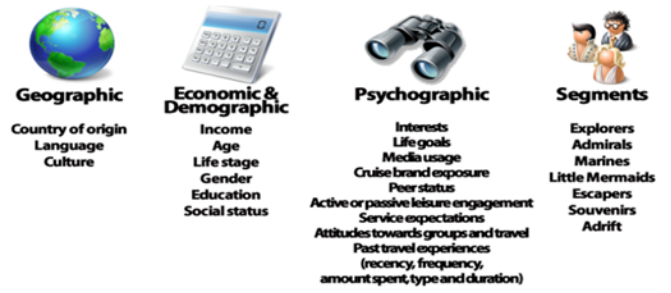

Fig. 2. A number of variables that predict cruise behaviour [13].

Table 2. Customer cruise segmentation to all destinations of Red Sea [13].

\begin{tabular}{|c|c|}
\hline Segment & $\begin{array}{l}\text { Estimated \% } \\
\text { of total } \\
\text { market by } \\
\text { trips to all } \\
\text { destinations of } \\
\text { Red Sea } \\
\end{array}$ \\
\hline $\begin{array}{l}\text { Explorers - These people take four or more vacations per year, have disposable incomes } \\
\text { and take longer cruises, exotic cruises and cultural learning cruises. Education and social } \\
\text { causes are important to them. So are making friends and socializing. It's a more saturated } \\
\text { segment, but one that is lucrative and important to satisfy to retain their business. This } \\
\text { group also represents future opportunity, as more couples become empty nesters and retired } \\
\text { upscale boomers. }\end{array}$ & 25 \\
\hline $\begin{array}{l}\text { Admirals - These people have selected their preferred cruise provider and seek a } \\
\text { traditional experience. They tend to ritualize their travel experience and don't usually } \\
\text { experiment unless their favorites start to become stale or so radically different the attributes } \\
\text { they admired become unrecognizable. Great cruise consumers, they tend to be older and a } \\
\text { good, loyal customer base but offer less opportunity for growth. }\end{array}$ & 20 \\
\hline $\begin{array}{l}\text { Marines - This desirable yet elusive segment is made up of upscale, motivated and active } \\
\text { young professionals. They are most likely to snorkel, para-sail, surf and rock climb. } \\
\text { Whether new or experienced cruisers, they are always auditioning better ships. They are } \\
\text { intellectually curious, media-involved, and they perceive value in not only the appearance } \\
\text { of being active but also the reality of learning and being challenged. Cruise companies can } \\
\text { grow well in this segment. They are the logical target for active ship design strategies as } \\
\text { well as expanding Internet marketing. }\end{array}$ & 15 \\
\hline $\begin{array}{l}\text { Little Mermaids - This segment is made up of upper middle class families. They are } \\
\text { experiencing an increase the pace of daily activity and a crunch for time. With every non- } \\
\text { working moment devoted to family errands (stopping at the Home Depot to pick up an } \\
\text { attachment for the air pump for the kids pool or running to Target for a new basketball for } \\
\text { the son's friends birthday party) they are looking to maximize leisure activity as a family } \\
\text { experience that includes opportunities for real quality-bonding. }\end{array}$ & 13 \\
\hline $\begin{array}{l}\text { Escapers - This is a desirable segment and probably the core of the cruise market. They } \\
\text { are just looking to get away. All-inclusive. No complications, no worries. From their point } \\
\text { of view, after having spent a hectic year, they have earned the pleasures of doing nothing } \\
\text { but sitting by the pool, seeing a few sites and relaxing. They are somewhat price sensitive } \\
\text { but will always find the money for the trip they deserve. }\end{array}$ & 12 \\
\hline $\begin{array}{l}\text { Souvenirs - These people have jobs (not careers) and lives (not lifestyles). Lacking intense } \\
\text { interest in the world outside they are primarily focused the internalized experience of the } \\
\text { moment. They tend to take a cruise vacation only when there's a "really good deal" that } \\
\text { everyone's talking about. }\end{array}$ & 8 \\
\hline $\begin{array}{l}\text { Adrift - There is a group of people in every society who are disconnected from travel } \\
\text { commerce, not curious about what's going on in the world and not likely to possess the } \\
\text { disposable income. This segment is a realistic target for the attention of breweries and } \\
\text { shops - not cruise line marketers. }\end{array}$ & 7 \\
\hline
\end{tabular}

\section{Cruise Trends}


The following trends in cruise tourism in the Red Sea were identified:

- According to our survey, the top reason travelers are interested in cruises is the ability to visit multiple destinations.

- More time in port. There are feature overnight stays, performances in port, and shore excursions, deeper connections with local people and cultures.

- The cruise industry has not been spared from quality and safety controversies linked to the COVID-19 pandemic. Given the current impacts that the pandemic has on cruising, it may take some time before the industry recovers and returns to a post-COVID-19 normal. Also, cruise liners will be expected to work more closely with public health authorities worldwide and CLIA (Cruise Lines International Association) to enforce health requirements.

- Sustainability matters, and cruise lines are responding to this travel transformation by implementing more environmentally friendly technology and programs to support the destinations they visit. By 2030, the cruise industry has committed to reducing its fleetwide rate of $\mathrm{CO}^{2}$ emissions by 40 percent, reports the Cruise Lines International Association.

- Micro-Cruises. It's exactly what it sounds like: short, close-to-home jaunts for travelers with little time, but a lot of desire to get away.

- Solo Travel. Travelers today are not afraid to venture out by themselves. They want the freedom to travel alone. This trend is only expected to apply to cruises as well as other forms of travel. Women are making more money than ever before. One place where women are putting their money is that of travel. Cruises are a huge part of this travel plan for many women. A safe and protected space where women can relax as they travel will continue to appeal to women all over the globe as they make their personalized travel plans each year.

- Work and play are a fact of life for many cruise lines today.

\section{Conclusions}

The Red Sea is part of the sea roads between Europe, the Persian Gulf and East Asia, and as such has heavy shipping traffic. The marine environment has long been one of the most attractive settings for tourism. Cruise tourism is one of the fastest growing areas within the world's largest industry. 11 cruise lines now represented in the Red Sea. First Class Cruise Lines and Premium Cruise Lines predominate in the Red Sea.

The Royal Caribbean International is a leader. The Oceania Cruises is an outsider.

MSC Cruises - the most active cruise line in the Red Sea. The cruise route programs in the Red Sea are represented by excursions to the regional historic places of interest. The cruise ships make stops for visiting museums, memorial complexes, historical places of interest. The primary reasons that consumers will be motivated to book a cruise in 20212022 and beyond, according to trends, include: good value offered by the cruise lines; love of cruising; get away with friends or alone; family reunions, honeymoons/weddings/anniversaries; try out new sustainable ships; shorter cruises; and «work and play» opportunity.

\section{References}

1. CLIA (2020). Cruise Lines International Association. https://www.cruising.org

2. Cruise Industry (2020). News MSC announces Red Sea itinerarie. http://www.cruiseindustrynews.com

3. Red Sea MSC Cruises. (2019). http://www.msccruises.com/gl en/CruiseDepartures/Find-Your-Cruise.aspx?Reg=RED\&ddl=y\&p=1\& 
4. Mullally, L. In search of bargains at sea: Deciphering the deals from cruise line. (2018). https://www.montereyherald.com/2010/11/21/in-search-of-bargains-at-sea-decipheringthe-deals-from-cruise-lines/ $\begin{array}{llll}\text { 5. Klein, R. A. The cost } \quad \text { of } & \text { cruising. } \\ \text { http://www.vancouverobserver.com/life/travel/2010/04/13/cost-cruising }\end{array}$

6. Cruise Lifestyles (2018).. Cruise Lines - To Suit Your Style. http://cruisediva.com/cruise style.htm

7. Duman, T., Mattila, A. S. (2005). The role of affective factors on perceived cruise vacation value. Tourism Management, 26(3), 311-323. https://doi.org/10.1016/j.tourman.2003.11.014

8. Hung, K., Petrick J. F. (2011). Why do you cruise? Exploring the motivations for taking cruise holidays, and the construction of a cruising motivation scale. Tourism Management, 32(2), 386-393. https://doi.org/10.1016/j.tourman.2010.03.008

9. Jones, R. V. (2011). Motivations to cruise: An itinerary and cruise experience study. Journal of Hospitality and Tourism Management, 18(1), 30-40. https://doi.org/10.1375/jhtm.18.1.30

10. Marti, B. E. (1991). Cruise ship market segmentation: a 'non-traditional' port case study. Maritime Policy and Management, 18(2), 93-103. https://doi.org/10.1080/03088839100000033

11. Parola, F., Satta, G., Penco, L., Persico, L. (2014). Destination satisfaction and cruiser behaviour: The moderating effect of excursion package. Research in Transportation Business and Management, (13), 53-64. https://doi.org/10.1016/j.rtbm.2014.11.001

12. Zhao, S., Timothy, D. J. (2017). Tourists' consumption and perceptions of red heritage. Annals of Tourism Research, (63), 97-111. https://doi.org/10.1016/j.annals.2017.01.003

13. Cruise Market Watch (2020).Cruise market segmentation; admirals and stowaways. https://cruisemarketwatch.com 